\title{
The Influence of Adding Turnip Roots (Brassica rapa var. rapa L.) Powder on The Antioxidant Activity and Acrylamide Content in some Fried Foods
}

\author{
Marwa, Z. Mahfouz ${ }^{1}$, Asteer V. Abd-Elnoor ${ }^{1}$, Ragwa I. Abd El-Razek ${ }^{1}$
}

\begin{abstract}
The current study was designed to add turnip roots powder to some fried foods, including chicken nuggets and Falafel, in order to reduce their acrylamide content and increase their nutritional value, glutathione content and antioxidant activity. Falafel prepared by adding three different percentages from turnip roots powder $(5,10$, 15\%). Also, turnip roots powder was added to both chicken meat and rusk powder at $5,10,15 \%$ in the preparation of chicken nuggets. The results showed that the best acceptable percentage for chicken nuggets was $10 \%$ while, Falafel was $5 \%$. The results indicated that the turnip roots powder contains moisture, ash, protein, crude fat, crude fiber, $\mathrm{N}$-free extract and calories as follows $(6.48 \pm 0.45 \%, 0.23 \pm 0.02 \%, \quad 5.47 \pm 0.72 \%, 0.56 \pm 0.23 \%$, $7.50 \pm 0.73 \%, 86.24 \pm 0.01$ and $371.88 \pm 008 \mathrm{DW}$, respectively). It has also been shown that chicken nuggets and Falafel prepared with turnip roots contained low fat and calories compared to the control, however they are rich in fiber and ash content. The glutathione content of turnip roots powder was $7.50 \pm 0.10 \mathrm{mg} / \mathrm{kg}$. A high level of glutathione was observed in Falafel and chicken nuggets after adding the turnip roots powder. The products prepared from turnip roots showed also higher radical scavenging activity than the other products. In addition, The highest percentages of flavonoids, total phenols, glutathione and antioxidants activity were detected in chicken nuggets and Falafel prepared from turnip roots. In contrast, the content of acrylamide decreased in chicken nuggets and Falafel prepared from turnip roots while increased in the control groups. There was a closed relationship between the antioxidant content and the formation of acrylamide. In conclusion, The efficiency of turnip roots was clearly proved through the data obtained from the in vitro samples, therefore (chicken nuggets and Falafel) that contained turnip roots powder are considered a good source of many bioactive compounds and antioxidants compared to chicken nuggets and Falafel prepared by traditional ingredients.
\end{abstract}

Keywords: Antioxidant activities; phenolic compound; chemical composition; acrylamide; turnip.

\section{INTRODUCTION}

Turnip root (Brassica rapa var. rapa) belongs to the Brassica genus, which is the most important genus of the Brassicaceae or Cruciferae family and it is one of the oldest cultivated vegetables that has been used for human consumption since prehistoric times. Nowadays, consumers are demanding nutrient-rich products for optimal health benefits, so turnip roots products are becoming more popular due to their nutritional value, anti-cancer, antioxidant and anti-inflammatory properties (Cartea et al., 2010). Furthermore, turnip roots contain antioxidants like vitamins $\mathrm{C}$ and $\mathrm{E}$, carotenoids that can prevent and treat malignant and degenerative diseases (Jahangir et al., 2009). These vegetables contain flavonoids, terpenes, sulphur-containing glucosinolates, anthocyanins, coumarins and other small compounds, which are useful plant metabolites (Harput et al., 2010). Also, Morales-Lopez et al. (2017) mentioned that, there are high amounts of phenolic compounds in the turnip roots, one of the bioactive compounds that have positive effects on human health. These compounds show antioxidant activity by inhibiting the biological activation of carcinogens and by increasing the detoxification of reactive oxygen species (ROS). Moreover, in turnip roots products, there is a high amount of folate that reduces vascular disease, cancer and neural tube defect risk (Czarnowska and Gujska, 2012).

Higdon et al. (2007) reported that turnip root is commonly known as Lifft in Egypt. Also, Liang et al. (2006) confirmed that Lifft is one of the oldest growing vegetables used since prehistoric times for human consumption. Turnip root is rich in vitamin $\mathrm{C}$ and is considered an antioxidant that can control and restrict the activities of free radicals and destructive reactions to oxidation. It is useful in the case of obesity, the rise in blood pressure, stomach, pancreas, bladder, diabetes and cancers (Liang et al., 2006). All these healthy benefits of this crop are due to the fact that it contains elements that are useful to our health such as carotenoids, minerals, vitamins, glucosinolates, phenols and flavonoids (Campbell et al., 2012). Also, because of their complicated mix of antioxidant active phytochemicals, the positive impacts of Brassica vegetables on health improvements were noted (Jahangir et al., 2009).

There are a lot of fried food recipes that contain vegetables as a main ingredient. One of the most famous fried vegetables is Falafel. Falafel is a fast traditional

DOI: 10.21608/ASEJAIQJSAE.2019.68841

${ }^{1}$ Home Economics Department, Nutrition \& Food Science, Faculty of Specific Education, Alexandria University

Received October 20, 2019, Accepted December 29, 2019 
food widely spread in the Middle East. It has multiple names that differ from place to place. It is known in Egypt and Sudan as "Ta'amiyya"; it is a small fried balls made from faba beans and / or chickpeas (Abdullah, 2015). It is considered a meal which is eaten at breakfast or dinner, especially in low-income families where it is consumed in large quantities because of its relatively low price and always available in addition to its distinctive taste (Amr and Abdulla, 2003).

Chicken products are a good source of animal protein, which contains all the essential amino acids that the body needs, in addition to its richness in unsaturated fatty acids and low cholesterol, especially when removing the skin (Shedeed, 1999). Restructured breaded products, such as chicken nuggets, are a consumption alternative to chicken meat widely accepted by consumers. Their main raw materials include chicken cuts, mechanically separated meat and skin. Preparation involves chicken muscle ground by a mechanical process, followed by mixing the remaining ingredients (Barros et al., 2018). Thus, chicken nuggets are battered and breaded, then deep-fried or baked and finally are quick frozen (Tamsen et al., 2018).

The high temperatures in the presence of water from dehydrated food and oxygen during the frying cycle resu It inpolymerization, oxidation, cyclization, peroxidation, hydrolysis, and isomerization of lipids, in addition to a variety of decomposition compounds that have a direct effect on oil quality, resulting in darkening of its color, and increase in viscosity (Bastida and Sánchez-Muniz 2001). Using frying oil more than once increases cooking time and reduces the heat transfer rate, which leads to increased oil penetration into the food. Therefore, the fried foods may contain significantly higher levels of thermoxidized and polymerized products that have undesirable long-term health effects and may develop chronic diseases (Totani et al. 2006). Thus, Falafel and chicken nuggets consumption may increase oxidative stress and related health risks.

Acrylamide is a compound formed during heat treatment as an intermediate product for Maillard reaction, which is formed by the interaction between amino acid asparagine and some reducing sugars. It is a soluble compound with low molecular weight (Stadler $e t$ al., 2002). It is demonstrated to be a source of different toxicities in animals and humans. The risk of acrylamide to health and its toxic properties have been demonstrated by the Scientific Committee on Toxicity, Ecotoxicity and the Environment in 2001(Zaied et al., 2016). Acrylamide occurs frequently in foods containing carbohydrates prepared by heating above $120^{\circ} \mathrm{C}$, when subjected to frying, grilling, and baking. It is not formed during boiling or microwaving.
This study aims to reduce acrylamide content and increase the nutritional value, glutathione and antioxidants content in some fried food products by adding turnip roots powder.

\section{MATERIALS AND METHODS}

\section{Materials}

The study materials included about $5 \mathrm{~kg}$ of fresh turnip brought from the central market of vegetables and fruits in Alexandria City, Egypt.

-The other components needed for preparing the food products were also obtained from the local markets in Alexandria, Egypt.

- Solvents and chemicals substances applied in this study were purchaced from El-Gomhorya Company.

\section{Methods}

\section{Preparation of turnip roots powder}

Turnip roots were washed carefully with tap water, and then cut into sliced and dried in an oven at $60^{\circ} \mathrm{C}$ for $36 \mathrm{~h}$ and then ground into fine powder. The turnip powder was packed in plastic bags till used (Saeed et al., 2012) and kept in frozen $-18^{\circ} \mathrm{C}$ until use.

\section{Preparation of products}

chicken nuggets and Falafel samples were prepared by mixing all ingredients according to the percentages shown in Table (1) and (2), respectively. The ingredients of chicken nuggets are presented in Table (1) according to Saba, (2005). The control samples were prepared without adding turnip powder to chicken meat and rusk powder. Turnip powder was added to both chicken meat and rusk powder at 5, 10 and $15 \%$. The minced chicken breasts were mixed with other ingredients, then the chicken nuggets were cut in different shapes and covered with flour, then scrambled eggs and rusk blends with turnip powder. Chicken nuggets were fried at $170^{\circ} \mathrm{C} / 5 \mathrm{~min}$ in mixture of soybean oil and sunflower oil.

The ingredients of Falafel are displayed in Table (2) according to Saba, (2005). The control sample was prepared without adding the turnip powder. The turnip powder was added to the paste of Falafel at 5, 10 and $15 \%$. Dehulled faba beans was soaked in double amount of water for 12 hat room temperature then drained and minced twice, where onion, food salt, parsley, coriandrum, dill, spices were added and then ingredients were mixed using the Kenwood mixer for 20 min until the texture became smooth and homogeneous balls can be formed (15 g each) and fried at $170^{\circ} \mathrm{C} / 4 \mathrm{~min}$ in mixture of soybean oil and sunflower oil. 
$\underline{\text { Table 1. Ingredients of chicken nuggets }}$

\begin{tabular}{lcccc}
\hline & \multirow{2}{*}{$\begin{array}{l}\text { Control } \\
\text { sample }\end{array}$} & \multicolumn{3}{c}{ Chicken nuggets with turnip roots powder } \\
\cline { 3 - 5 } & $(\mathbf{g})$ & $\mathbf{5 \%}$ & $\mathbf{1 0 \%}$ & $\mathbf{1 5 \%}$ \\
\hline Minced chicken breasts & 100 & 100 & 100 & 100 \\
Turnip roots powder & 0 & 5 & 10 & 15 \\
Rusk powder & 70 & 65 & 60 & 55 \\
Chopped raw onion & 40 & 40 & 40 & 40 \\
Food salt & 5 & 5 & 5 & 5 \\
Black pepper & 1 & 1 & 1 & 1 \\
Wheat flour & 50 & 50 & 50 & 50 \\
Eggs & 100 & 100 & 100 & 100 \\
Total & 366 & 371 & 376 & 381 \\
\hline
\end{tabular}

Table 2. Ingredients of Falafel

\begin{tabular}{lcccc}
\hline \multirow{2}{*}{ Ingredients (g) } & Control sample & \multicolumn{3}{c}{ Falafel with turnip roots } \\
\cline { 3 - 5 } & $(\mathbf{g})$ & $\mathbf{5 \%}$ & $\mathbf{1 0 \%}$ & $\mathbf{1 5 \%}$ \\
\hline Dehulled faba beans & 100 & 100 & 100 & 100 \\
Turnip roots powder & 0 & 5 & 10 & 15 \\
Chopped raw onion & 30 & 30 & 30 & 30 \\
Parsley & 10 & 10 & 10 & 10 \\
Chopped coriandrum & 10 & 10 & 10 & 10 \\
Chopped dill & 10 & 10 & 10 & 10 \\
Spices & 1 & 1 & 1 & 1 \\
Food salt & 1 & 1 & 1 & 1 \\
Total & 162 & 167 & 172 & 177 \\
\hline
\end{tabular}

\section{Sensory evaluation}

The sensory characteristics of the samples were evaluated according to Aljdely and Hemida (2002) by 25 panelists from staff, employees and students of Faculty of Specific Education, Alexandria University. Parameters were taste, color, consistency, odor and the overall acceptability which was determined as the total mean score of all the sensory parameters. A scale of 9point hedonic scale with ranging from 1(representing extreme dislike) to 9 (representing extreme like) was used to evaluate the sensory attributes.

Proximate analysis, total polyphenols and antioxidant activity were conducted only on the samples that gained the highest scores by panelists along with their corresponding controls.

\section{Proximate composition}

Moisture and ash content were determined according to AOAC (2007). Crude protein content was estimated by the micro Kjeldahl's method as described by (AOAC 2007). The total nitrogen was calculated by multiplying the factor of 6. 25. Total fat was extracted by chloroform-methanol according toFolch et al.(1987).
The N-free extract content was obtained by subtracting the percent total of the fat, protein, fiber and ash contents from $100 \%$.Caloric values were calculated from the sum of the percentages of crude protein and $\mathrm{N}$ free extract multiplied by a factor of $4(\mathrm{kcal} . \mathrm{g}-1)$ plus the crude fat content multiplied by a factor of 9 (kcal.g1)according to Zambrona et al. (2004).

Total polyphenol content was carried out according to Elfalleh et al. (2009).Total flavonoids content in the extracts was measured spectrophotometrically using the method of Djeridane et al. (2006). Phenolic compounds were determined by HPLC according to the method of Goupy et al. (1999). Individual flavonoids were determined according to Jin et al. (2004). Antioxidant activities (DPPH radical scavenging activity) was determined according to the method of Brand-Williams et al. (1995). The scavenging activity of extract towards hydrogen peroxide radicals was determined by the method of Ngonda (2013).

The $\mathrm{IC}_{50}$ is defined as the concentration of antioxidant necessary to decrease the initial DPPH concentration to $50 \%$. The $\mathrm{IC}_{50}$ of the samples was derived from the $\%$ scavenging activity $v s$. concentration plot and is expressed as $\mathrm{mg} / \mathrm{ml}$. Glutathione was 
determined by HPLC according to the method of Lipsa et al. (2015). Acrylamide (AA) content was determined by HPLC according to the method of Gökmen et al. (2005).

\section{Statistical analysis}

The data were analyzed using IBM SPSS software package version 20.0. (Armonk, NY: IBM Corp) as outlined by Kirkpatrick and Feeney (2013). Quantitative data were described using mean \pm standard deviation.The significance of the obtained results was judged at the 5\% level (Kotz et al., 2006).To compare between two groups under study, the normally distributed quantitative variables were used ( $\mathrm{t}$-test).

\section{RESULTS AND DISCUSSION}

\section{Sensory evaluation of the chicken nuggets and Falafel supplemented with turnip roots powder}

The sensory scores of chicken nuggets and Falafel evaluated by 25 panelists are shown in Table (3). Three concentrations of turnip roots powder were added at 5 , 10 , and $15 \%$. These concentrations were the best accepted after testing many other concentrations during the pilot study performed before starting the research. The color, odor, consistency, taste and acceptance of the chicken nuggets in the control group and 5\% were not significantly affected by the adding of turnip roots powder. However, $10 \%$ and $15 \%$ were significantly affected $(P \leq 0.05)$ by adding this powder.

It can be observed from Table (3) that the taste of chicken nuggets when using $10 \%$ concentration of turnip roots powder was insignificantly higher than the values of 5 and $15 \%$ (9.76 vs. 8.24 and 7.68, respectively). On the other hand, the mean values of color of the control, $5,10,15 \%$ of chicken nuggets were $9.32,9.04,9.64$ and 8.84 , respectively. These results revealed that, the highest mean of color was shown in the control and $10 \%$ of chicken nuggets while the lowest was in 5 and $15 \%$ of chicken nuggets. Odor means were found to increase by adding high amount of turnip roots powder (10\%) . As shown in Table (3), it could be noted that there were no significant differences $(P \leq 0.05)$ in the mean values of overall acceptability for control sample, 5 and $10 \%$, also between control chicken nuggets and $15 \%$ samples. The results revealed that the highest mean value of consistency was $(9.00 \pm 0.20)$ for $10 \%$ chicken nuggets compared to other samples. Besides, adding turnip powder at $10 \%$ increased the level of overall acceptability $(9.04 \pm 0.13)$ compared to 5 and $15 \%$ chicken nuggets $(8.92 \pm 0.13,8.24 \pm 0.22)$, respectively. In the light of data presented here, the chicken nuggets with $10 \%$ turnip roots powder were chosen to perform the chemical analysis because it gave the best results in sensory evaluation compared to other concentrations.
The color, taste, consistency, odor and overall acceptability of Falafel were significantly affected $(P \leq 0.05)$ by adding turnip roots powder. It can be observed from Table (3) that the mean value of the color of sample containing 5\% turnip powder was significantly higher than the mean values of 10 and $15 \%$ samples (9.44 vs. 7.76and 8.20, respectively). On the other hand, the mean values of odor of the control, 5 , $10,15 \%$ samples were 9.00, 9.24, 7.60and 7.88, respectively. These results revealed that, the highest mean of consistency was shown in the control and 5\% samples while the lowest was in 10 and $15 \%$ samples. Taste means were found to increase by adding turnip powder at $5 \%$. The taste mean of $10 \%$ sample was significantly higher than the value of $15 \%$ sample (7.24vs. 6.88, respectively) but insignificantly with $5 \%$ sample. It was obvious that adding turnip roots powder at $5 \%$ led to an increase in the level of the overall acceptability $(9.26 \pm 0.19)$ compared to 10 and $15 \%$ samples (7.96 \pm 0.29 and $7.64 \pm 0.28$, respectively).

The sample of Falafel containing $5 \%$ turnip roots powder concentration was chosen to perform the chemical analysis because it gave the best results in terms of sensory evaluation compared to other concentrations. The results suggested that turnip can economically be added to chicken nuggets and Falafel and can yield products of highly acceptable quality and high nutritional value. Chicken nuggets and Falafel with turnip roots powder were mostly higher in antioxidant activity and were more acceptable.

These results are consistent with the findings of Mousavinejad et al. (2009) who observed that inherently phenolic compounds correlate with sensory features of food such as color, astringency, and flavor. Colored flavonoids, anthocyanins are the most important group of plant pigments due to their antioxidant activity and other useful biological characteristics (McDougall et al., 2007).

\section{Proximate composition of turnip roots powder and its products}

Table (4) shows the proximate composition of the turnip roots powder and its products. The values of moisture, protein, total fat, ash, crude fiber, $\mathrm{N}$-free extract and calories for turnip powder were found to be $6.48 \pm 0.45,5.47 \pm 0.72,0.56 \pm 0.23,0.23 \pm 0.02,7.50 \pm 0.73$ , 86.24 \pm 0.01 and $371.88 \pm 0.08(\mathrm{~g} / 100 \mathrm{~g} \mathrm{DW})$, respectively. The USDA, (2008) determined the energy and nutrient content of 100 grams of turnip and found that the content of protein, carbohydrate, total fat , fiber, energy and water were $1.17,6.43,0.13,1.8,28$ and 91.87, respectively. However, Hussain et al. (2013) pointed out different results, they previously indicated that the values of moisture, total protein, fats, ash, crude fiber 
and carbohydrates were found to be $11.14 \pm 0.18,2.30 \pm$ $0.02,0.23 \pm 0.04,0.61 \pm 0.04,0.77 \pm 0.01$ and $85.71 \pm$ 0.32) . Also, Saeed et al. (2012) noted that the dietary value of white turnips and yellow turnips was small in fat and calories but high in fiber and the energy value of white turnips was slightly greater than the yellow turnip variety. Such slight variation depends on the variety and the region.

On the other hand, it is clear that chicken nuggets mixed with turnip significantly contain more protein $(49.06 \pm 0.29)$ fiber $(5.00 \pm 0.02)$ and ash (7.41 \pm 0.29$)$ content $(P \leq 0.05)$ than the control chicken nuggets (47.45 $\pm 0.11,4.66 \pm 0.20$ and $5.59 \pm 0.04$, respectively ). While adding turnip to chicken nuggets resulted in a significant $(P \leq 0.05)$ decrease in total fats $(9.75 \pm 0.03)$ $\mathrm{N}$-free extract $(28.78 \pm 0.18)$ and calories $(399.11 \pm 0.45$ )compared to the control chicken nuggets. On the other hand, the adding of turnip roots powder to Falafel at 5\% caused an increase in protein $(15.39 \pm 0.48)$ fiber $(11.16 \pm 0.51)$ and $\operatorname{ash}(3.42 \pm 0.84)$ compared to the control Falafel ( $13.17 \pm 0.17,11.9 \pm 0.36$ and $2.72 \pm$ 0.67 , respectively). It also caused a decrease in total fats and $\mathrm{N}$-free extract by $27.06 \pm 0.35$ and $42.23 \pm 0.46$, respectively.
Santhi and Kalaikannan (2014) determined the proximate composition of chicken nuggets and found that moisture, crude fiber, crude protein, fat, total ash and gross energy $(\%)$ were $57.40 \pm 1.04,0.76 \pm 0.05$, $18.03 \pm 0.35,3.02 \pm 0.12,1.76 \pm 0.31$ and $1871 \pm$ 48.43.The United States Department of Agriculture (USDA, 2019) reported that homemade Falafel contains $13.3 \%$ proteins, $31.8 \%$ carbohydrate and $17.8 \%$ total fat.

\section{Antioxidant activity and phytochemicals of turnip roots powder and its products:}

The antioxidant activity of turnip roots powder and its products was estimated by using different methods such as total phenolic content, total flavonoids, $\mathrm{H}_{2} \mathrm{O}_{2} \%$, $\mathrm{IC}_{50}$ and DPPH radical scavenging activity. Results in Table (5) show that turnip roots powder has high values for DPPH (78.39\% antioxidant activity), $\mathrm{H}_{2} \mathrm{O}_{2}\left(45.78 \%\right.$ antioxidant activity ) and the value of $\mathrm{IC}_{50}$ for turnip powder was $0.017 \mu \mathrm{g} / \mathrm{ml}$. In the present study, two ways were used based on the studies of Schlesier $e t$ al. (2002) to determine antioxidant activity, They showed that determination of the activity of the antioxidant of foods and food extracts can't be investigated by one method. It is recommended to use two tests at least.

Table 3. Sensory evaluation of the chicken nuggets and Falafel supplemented with turnip roots powder

\begin{tabular}{lcccccc}
\hline \multirow{2}{*}{ Products } & \multicolumn{5}{c}{ Sensory attributes } \\
\cline { 2 - 6 } & & Color & Odor & consistency & Taste & $\begin{array}{c}\text { overall } \\
\text { acceptability }\end{array}$ \\
\cline { 2 - 6 } & Control & $9.32^{\mathrm{a}} \pm 0.10$ & $8.72^{\mathrm{b}} \pm 0.09$ & $8.20^{\mathrm{b}} \pm 0.17$ & $8.28^{\mathrm{b}} \pm 0.18$ & $8.72^{\mathrm{a}} \pm 0.09$ \\
Chicken & $5 \%$ & $9.04^{\mathrm{b}} \pm 0.11$ & $8.64^{\mathrm{b}} \pm 0.15$ & $8.52^{\mathrm{b}} \pm 0.18$ & $8.24^{\mathrm{b}} \pm 0.20$ & $8.92^{\mathrm{a}} \pm 0.13$ \\
nuggets & $10 \%$ & $9.64^{\mathrm{a}} \pm 0.17$ & $9.28^{\mathrm{a}} \pm 0.21$ & $9.00^{\mathrm{a}} \pm 0.20$ & $9.76^{\mathrm{a}} \pm 0.12$ & $9.04^{\mathrm{a}} \pm 0.13$ \\
& $15 \%$ & $8.84^{\mathrm{c}} \pm 0.17$ & $7.72^{\mathrm{c}} \pm 0.09$ & $7.72^{\mathrm{c}} \pm 0.09$ & $7.68^{\mathrm{c}} \pm 0.21$ & $8.24^{\mathrm{b}} \pm 0.22$ \\
& Control & $9.16^{\mathrm{a}} \pm 0.24$ & $9.00^{\mathrm{a}} \pm 0.27$ & $8.48^{\mathrm{b}} \pm 0.19$ & $9.04^{\mathrm{b}} \pm 0.14$ & $9.08^{\mathrm{a}} \pm 0.13$ \\
& $5 \%$ & $9.44^{\mathrm{a}} \pm 0.23$ & $9.24^{\mathrm{a}} \pm 0.18$ & $9.02^{\mathrm{a}} \pm 0.25$ & $9.14^{\mathrm{a}} \pm 0.23$ & $9.26^{\mathrm{a}} \pm 0.19$ \\
Falafel & $10 \%$ & $7.76^{\mathrm{b}} \pm 0.28$ & $7.60^{\mathrm{b}} \pm 0.36$ & $7.60^{\mathrm{c}} \pm 0.28$ & $7.24^{\mathrm{b}} \pm 0.25$ & $7.96^{\mathrm{b}} \pm 0.29$ \\
& $15 \%$ & $8.20^{\mathrm{b}} \pm 0.27$ & $7.88^{\mathrm{b}} \pm 0.31$ & $7.92^{\mathrm{b}} \pm 0.31$ & $6.88^{\mathrm{b}} \pm 0.33$ & $7.64^{\mathrm{b}} \pm 0.28$ \\
\hline
\end{tabular}

Means in a column not sharing the same letter are significantly different at $P \leq 0.05$

Table 4. Chemical composition of turnip roots powder and its products (on dry weight basis)

\begin{tabular}{cccccc}
\hline \multirow{2}{*}{ Parameters } & Turnip powder & \multicolumn{2}{c}{ Chicken nuggets } & \multicolumn{2}{c}{ Falafel } \\
\cline { 3 - 6 } & & Control & Nug/Br** & Control & Falafel/Br**** \\
\hline Moisture (\%) & $6.48 \pm 0.45$ & $60.17^{\mathrm{b}} \pm 0.34$ & $61.05^{\mathrm{a}} \pm 0.25$ & $32.85^{\mathrm{b}} \pm 0.31$ & $33.70^{\mathrm{a}} \pm 0.89$ \\
Protein (\%) & $5.47 \pm 0.72$ & $47.45^{\mathrm{b}} \pm 0.11$ & $49.06^{\mathrm{a}} \pm 0.29$ & $13.17^{\mathrm{b}} \pm 0.17$ & $15.39^{\mathrm{a}} \pm 0.48$ \\
Total Fats (\%) & $0.56 \pm 0.23$ & $11.55^{\mathrm{a}} \pm 0.71$ & $9.75^{\mathrm{b}} \pm 0.03$ & $27.24^{\mathrm{a}} \pm 0.24$ & $27.06^{\mathrm{b}} \pm 0.35$ \\
Crude fibers (\%) & $7.50 \pm 0.73$ & $4.66^{\mathrm{b}} \pm 0.20$ & $5.00^{\mathrm{a}} \pm 0.02$ & $11.9^{\mathrm{a}} \pm 0.36$ & $11.16^{\mathrm{b}} \pm 0.51$ \\
Ash (\%) & $0.23 \pm 0.02$ & $5.59^{\mathrm{b}} \pm 0.04$ & $7.41^{\mathrm{a}} \pm 0.29$ & $2.72^{\mathrm{b}} \pm 0.67$ & $3.42^{\mathrm{a}} \pm 0.84$ \\
N-free extract (\%)* & $86.24 \pm 0.01$ & $30.75^{\mathrm{a}} \pm 0.06$ & $28.78^{\mathrm{a}} \pm 0.18$ & $45.71^{\mathrm{a}} \pm 0.63$ & $42.23^{\mathrm{b}} \pm 0.46$ \\
Calories & $371.88 \pm 0.08$ & $416.75^{\mathrm{a}} \pm 0.90$ & $399.11^{\mathrm{b}} \pm 0.45$ & $480.68^{\mathrm{a}} \pm 0.63$ & $474.02^{\mathrm{b}} \pm 0.45$ \\
(Kcal/100g) & & & & &
\end{tabular}

Comparing between the studied groups using student t- test

Means with Common letters are not significant (i.e. Means with different letters are significant at $P \leq 0.05$ )

Values are mean of three replicates \pm SD.N-free extract $(\%) *$ calculated by difference)

Key: $\mathrm{Nug} / \mathrm{Br}^{* *}$ : Chicken nuggets supplemented with turnip \%Fal/Br***:Falafel supplemented with turnip roots powder. 
Table 5. Phytochemicals content and antioxidant activity of turnip roots powder and its products

\begin{tabular}{cccccc}
\multirow{2}{*}{ Parameters } & Turnip roots & \multicolumn{2}{c}{ Chicken nuggets } & \multicolumn{2}{c}{ Falafel } \\
\cline { 2 - 6 } powder & Control & Nug/Br & Control & Fal/Br \\
\cline { 2 - 5 } Total phenolic $\mu \mathrm{g} / \mathrm{g}$ & $63.47 \pm 3.10$ & $82.76^{\mathrm{b}} \pm 0.63$ & $93.72^{\mathrm{a}} \pm 0.67$ & $97.13^{\mathrm{b}} \pm 0.28$ & $118.40^{\mathrm{a}} \pm 0.52$ \\
Total flavonoids $\mu \mathrm{g} / \mathrm{g}$ & $34.56 \pm 1.05$ & $12.74^{\mathrm{b}} \pm 0.48$ & $17.97^{\mathrm{a}} \pm 0.09$ & $15.11^{\mathrm{b}} \pm 0.54$ & $28.44^{\mathrm{a}} \pm 0.05$ \\
$\mathrm{DPPH} \%$ & $78.39 \pm 3.50$ & $45.78^{\mathrm{b}} \pm 0.73$ & $66.57^{\mathrm{a}} \pm 0.51$ & $61.70^{\mathrm{b}} \pm 0.60$ & $73.00^{\mathrm{a}} \pm 0.94$ \\
$\mathrm{H}_{2} \mathrm{O}_{2} \%$ & $45.78 \pm 0.73$ & $28.02^{\mathrm{b}} \pm 0.58$ & $32.92^{\mathrm{a}} \pm 0.67$ & $39.41^{\mathrm{b}} \pm 1.20$ & $43.66^{\mathrm{a}} \pm 1.36$ \\
$\mathrm{IC}_{50} \mu \mathrm{g} / \mathrm{ml}$ & 0.017 & 0.075 & 0.056 & 0.029 & 0.022 \\
\hline
\end{tabular}

Values are mean of three replicates \pm SD

Means with Common letters are not significant (i.e. Means with Different letters are significant at $P \leq 0.05$ )

Significant was done using Student t-test

Key: Nug/Br**: Chicken nuggets supplemented with turnip $\% \mathrm{Fal} / \mathrm{Br}^{* * *}:$ Falafel supplemented with turnip roots powder.

Total phenolics and flavonoids of the raw turnip root powder (on dry weight basis) are shown in Table (5). It could be noted that turnip root powder had the highest level of total phenolics $(63.47 \mathrm{mg} / \mathrm{g})$ and had moderate of flavonoids $(34.56 \mathrm{mg} / \mathrm{g})$. These data are in line with data reported by Zhang et al. ( 2008). Also, Kaur and Kapoor (2002) estimated total phenolics content in turnip and found it (127.0 mg/100g). Ali and Naz (2017) found that the total phenolics content, flavonoids content, DPPH and $\mathrm{IC}_{50}$ in turnip pulp were 4.051 $(\mathrm{mg} / \mathrm{g}), 2.889(\%), 5.095(\mathrm{mg} / \mathrm{ml})$ and $\mathrm{IC}_{50} 5.114 \pm 0.0125$ $(\mathrm{mg} / \mathrm{ml})$,respectively.The antioxidant capacity of turnip was related to its phenolic profile and content,particularl y flavonoids, as phenolic compounds exhibited greater a ntioxidant activity than carotenoids and vitamins (Podsędek, 2007 ), therefore Berdja et al. (2016) concluded that turnip roots powder corrects oxidative markers, inflammatory and metabolic parameters in the blood and homogeneous tissue and decreases lipid droplets in the liver. It has been observed that polyphenolic compounds play a preventive role in the progress of chornic and degenerative cases such as patients with cardiovascular diseases, diabetes and cancer (Thiruvengadam et al., 2014 ).

Total flavonoids, total phenolics, $\mathrm{DPPH}(\%)$, $\mathrm{H}_{2} \mathrm{O}_{2}(\%)$ and $\mathrm{IC}_{50}$ in Falafel and chicken nuggets supplemented with turnip root powder are tabulated in Table (5). Chicken nuggets supplemented with turnip roots powder possessed significantly $(P \leq 0.05)$ the highest level of total flavonoids, total phenolics, DPPH $(\%), \mathrm{H}_{2} \mathrm{O}_{2}(\%)$ and the lowest level of $\mathrm{IC}_{50}$ at $17.97 \pm$ $0.09 \mathrm{mg} / \mathrm{g}, 93.72 \pm 0.67 \mathrm{mg} / \mathrm{g}, 66.57 \%, 32.92 \%$ and 0.056 $\mathrm{mg} / \mathrm{ml}$, respectively compared to the control chicken nuggets without turnip roots powder $(12.74 \pm 0.48 \mathrm{mg} / \mathrm{g}$, $82.76 \pm 0.63 \mathrm{mg} / \mathrm{g}, 45.78 \%, 28.02 \%$ and $0.075 \mathrm{mg} / \mathrm{ml}$, respectively). On the other hand, the results reveal that total flavonoids, total phenolics, DPPH (\%), $\mathrm{H}_{2} \mathrm{O}_{2}(\%)$ and $\mathrm{IC}_{50}$ in Falafel supplemented with turnip powder were $(28.44 \pm 0.05 \mathrm{mg} / \mathrm{g}),(118.40 \pm 0.52 \mathrm{mg} / \mathrm{g})$, $(73.00 \%)(43.66 \%)$ and $(0.022 \mathrm{mg} / \mathrm{ml})$ respectively . In contrast, Falafel without turnip roots powder exhibited significantly $(P \leq 0.05)$ the less amount of total flavonoids $(15.11 \pm 0.54 \mathrm{mg} / \mathrm{g})$, total phenolics $(97.13 \pm$ $0.28 \mathrm{mg} / \mathrm{g})$, DPPH (61.70 \%), $\mathrm{H}_{2} \mathrm{O}_{2}(39.41 \%)$ and high $\mathrm{IC}_{50}(0.029 \mu \mathrm{g} / \mathrm{ml})$. These results are in agreement with Romani et al. (2006) who argued that turnip contains great amounts of biological active compounds including flavonoids such as (isorhamnetin compound, and other components such as kaempferol, quercetin, glycosides). Also, Beltagy (2014) observed that plant roots of turnip caused elevated levels of antioxidant activity, as more antioxidant activity comes from the turnip root than the leaves. Moreover, Ryu et al. (2012) revealed that ethanol extract from turnip roots had an inhibitory activity against lipid peroxidation. Also, they indicated that the antioxidant activity of the turnip roots positively correlated with their total phenolics content.

Wachtel-Galor et al. (2008) found that the turnip has greater antioxidant activity than three species of $B$. oleracea plants (broccoli, cabbage and cauliflower). Moreover, Saeed et al. (2012) found that the edible parts in turnip showed a scavenging ability against DPPH. The antioxidant activity (\% inhibition) of white turnip ranged from 18 to $65 \%$ while the antioxidant activity (DPPH) of yellow turnip ranged from 23 to $72 \%$ at concentrations of $(0.5-3.0 \mathrm{mg} / \mathrm{ml})$.

As shown in Table (5), there is an inverse relationship between $\mathrm{IC}_{50}$ and antioxidant activity in all samples, Lower $\mathrm{IC}_{50}$ value indicates higher antioxidant activity. Therefore, it was found that as a result of the rise in antioxidants in chicken nuggets and Falafel supplemented with turnip roots powder, led to a decrease in the value of $\mathrm{IC}_{50}$ compared to the control.Generally,from data presented in Table (5) there is a large increase in the total phenolics, total flavonoids, DPPH (\%), $\mathrm{H}_{2} \mathrm{O}_{2}(\%)$ of the studied chicken nuggets and Falafel after the addition of turnip roots powder.These results indicate the efficiency of turnip roots powder in improvement the health benefits and functionality of the fortified food. 


\section{Phenolic acids of chicken nuggets and Falafel supplemented with turnip roots powder:-}

Figure (1) illustrates the concentration of individual phenolic compounds in chicken nuggets and Falafel before and after the addition of turnip roots powder. It was clear that there was a significant increase in almost all studied individual phenolic compounds after the addition of turnip to chicken nuggets as follow: ellagic acid, chlorogenic acid, t-cinnamic and caffeic acid ranged from (15.54 to 24.28), (ND to 1.00), (11.09to $14.04)$ and (0.72 to1.43), respectively except gallic acid and sinapic acid that being exhibited slightly decrease in their concentration from (8.03to 7.26) and (4.94to 3.56). Also, the concentration of ferulic acid was almost stable in chicken nuggets being in a range from 3.51to $3.77 \mu \mathrm{g} / \mathrm{g}$.

On the other hand, it was obvious that $p$-coumaric acid in supplemented Falafel exhibited the highest content among other individual phenolic compounds as it was $17.93 \mu \mathrm{g} / \mathrm{g}$. Also, the concentration of ferulic acid slightly decreased in Falafel from 6.47to $5.79 \mu \mathrm{g} / \mathrm{g}$. Harbaum et al. (2007) found that the basic polyphenols compounds in turnip vegetables are arequercetin, tetraglucosides, isorhamnetin and acylated mono-, di-, tri- and kaempferol, as well as esters of hydroxyl cinnamic acids with quinic acid, malic acid, and glycosides. Polyphenolic compounds are very important vegetables constituents, by strength of their antioxidant capacity to reduce formation lipid oxidation and acrylamide.

Fernandes et al. (2007) found 14 phenolic compounds:- isorhamnetin 3-o- glucoside, 3-pcoumaroylquinic, sinapic, caffeic acids, ferulic, kaempferol 3-o- (feruloyl/caffeoyl)- sophorosidediglucoside, kaempferol 3-o- sophoroside- 7-oglucoside isorhamnetin 3, kaempferol3, kaempferol 3$o$-sophoroside -7-o- sophoroside, kaempferol 3-osophoroside, 1,2- disinapoylgentiobiose, 1,20-disinapoyl -2- feruloylgentiobiose, 7-o-glucoside, 7-o- kaempferol 3-o-glucoside and 7-o-diglucoside in turnip var. rapa $L$.

\section{Flavonoids content of chicken nuggets and Falafel supplemented with turnip roots powder versus their controls:-}

Figure (2) illustrates a significant increase in the concentration of studied individual flavonoids found in chicken nuggets and Falafel supplemented with turnip roots powder. The concentration of orientin showed a slight decrease in chicken nuggets supplemented with turnip roots powder from 4.84 to $4.46 \mu \mathrm{g} / \mathrm{g}$, while kaempferol and puerarin increased from 6.17 to11.83 and 4.09 to $12.14 \mu \mathrm{g} / \mathrm{g}$, respectively.

These results reveal that rutin slightly decreased after addition of turnip in Falafel from 5.71to $4.70 \mu \mathrm{g} / \mathrm{g}$, while the puerarin and glyciteine in Falafel supplement with turnip was the highest content that ranged from (0 to $5.83 \mu \mathrm{g} / \mathrm{g})$ and $(7.02$ to $7.43 \mu \mathrm{g} / \mathrm{g})$. Shafek et al. (2018) reported the presence of 16 flavonoid compounds in turnip namely:- kaempferol- 3-O-Sophoroside -7-O- $\beta$ D-glucoside (L1), 7-O- $\beta$ D - d-glucopyranoside (L2) (the new compound), quercetin $3,7-O$ - $\beta$-Ddiglucopyranoside (L3), kaempferol $-3,7-O-\beta-\quad \mathrm{D}-$ diglucopyranoside (L4), kaempferol -3-O-Sophoroside (L5), quercetin- 3-O-Sophoroside (L6) isorhamnetin-3$O$ - $\alpha$-L-rhamnopyranosyl- $(1 \rightarrow 6)-\beta$-D- glucopyranoside (L7), quercetin 3-O $-\beta-\quad \mathrm{D}-$ glucopyranoside (L9),kaempferol 7-O- $\beta$ - D-glucopyranoside (L13), kaempferol (L14), quercetin 7-O - $\beta$ - D- glucopyranoside (L10),isorhamnetin 3-O- $\beta$ - $\quad$ D-glucopyranosyl $\left(1^{\prime \prime \prime \prime} \rightarrow 2^{\prime \prime \prime}\right)-\alpha$-L-rhamnopyranosyl $\left(1^{\prime \prime \prime} \rightarrow 2^{\prime \prime}\right)$ - kaempferol3, isorhamnetin-3-O- $\beta$-D- glucopyranoside (L11), isorhamnetin- 3-O- $\alpha$ - L-rhamnopyranosyl- $(1 \rightarrow 2)-\beta \mathrm{D}$ glucopyranoside L8), kaempferol 3-O- $\beta$ - Dglucopyranoside (L12),quercetin (L15) and isorhamnetin (L16). Sousa et al. (2008) carried out a comparative study about Brassica in florescences, he found that turnip roots powder contained a number of flavonoids and phenolic acids.

The published data support phenolics' role in preventing various chronic diseases, including many cancer types, enhancing the phenolic load of plant origin foods would clearly benefit people's health by dietary intervention. Plant geneticists have attempted to enhance phytochemical concentrations by traditional breeding programs or bioengineering with phenylalanine ammonialyase (PAL) leading to secondary accumulation of metabolites (Cartea et al., 2010).

Rokayya et al. (2014) demonstrated that flavonoids ' bio-efficacy depends largely on their bioavailability. Such chemical composition and the physical properties of food matrices may delay or increase flavonoids absorption. Grumbles (2008) showed that chicken nugget was the only nugget accepted worldwide that had reached a high level of popularity compared to other meat products. Also, Falafel or Ta' mia is an Egyptian staple food produced from dehulled faba beans (Ismail et al., 2017), so it is advisable to add turnip roots powder for popularly consumed products such as Falafel and chicken nugget to obtain a high nutritional value and bioactive compounds. 

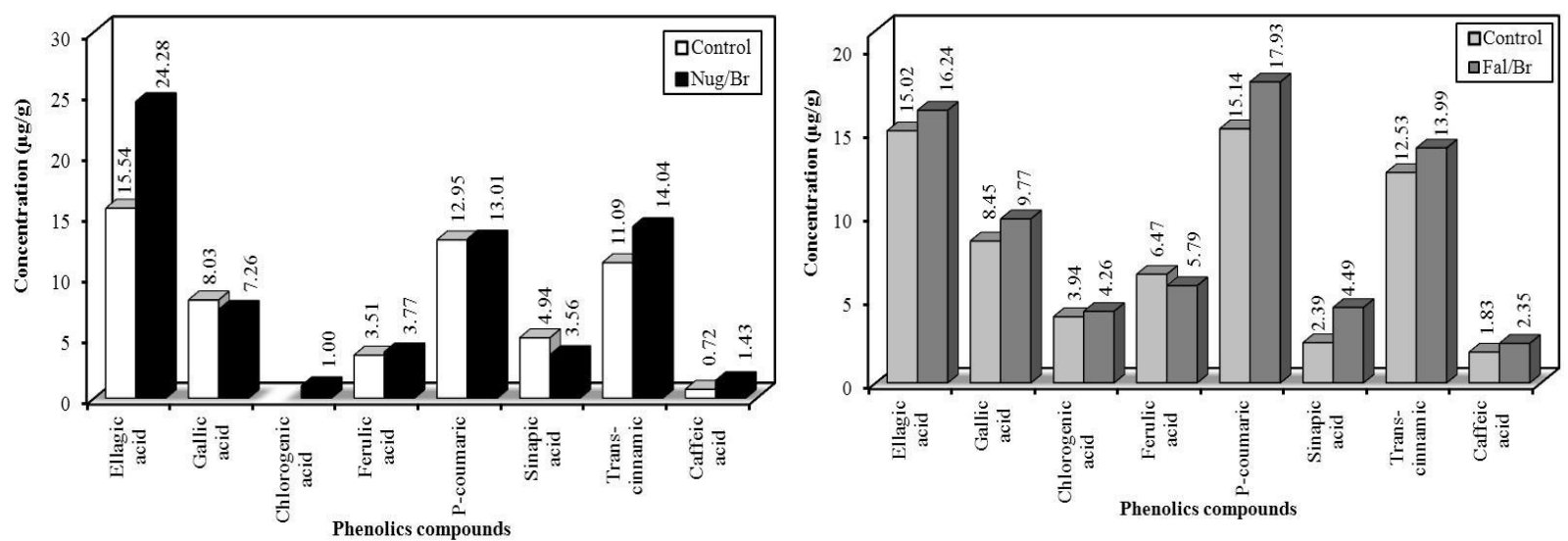

Figure 1. Individual phenolic compounds in chicken nuggets and Falafel

Key: Nug/Br**: Chicken nuggets supplemented with turnip roots powder\%

$\mathrm{Fal} / \mathrm{Br}^{* * *}:$ Falafel supplemented with turnip roots powder\%
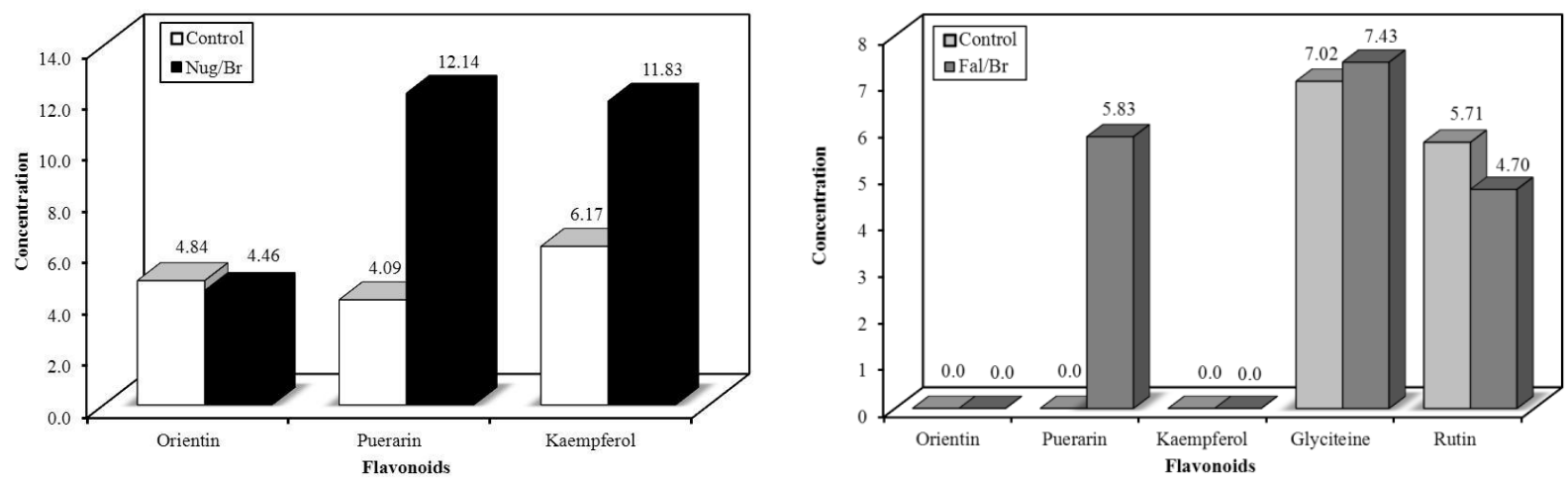

Figure 2. Individual flavonoids elements in chicken nuggets and Falafel

Key: Nug/Br**: Chicken nuggets supplemented with turnip roots powder\%

$\mathrm{Fal} / \mathrm{Br}^{* * *}:$ Falafel supplemented with turnip roots powder\%

\section{Glutathione contentof turnip roots powder and its products}

The data illustrated in Table (6) reveal that the glutathione content of turnip powder was $7.50 \pm 0.10$ $\mathrm{mg} / \mathrm{kg}$, while the highest contents of glutathione were recorded for chicken nuggets and Falafel supplemented with turnip powder by $(19.11 \pm 0.10$ and $13.17 \pm 0.17$ $\mathrm{mg} / \mathrm{kg}$, respectively) compared with chicken nuggets and Falafel without turnip roots powder $(13.80 \pm 0.73$ and $8.85 \pm 0.02 \mathrm{mg} / \mathrm{kg}$, respectively). An increase in the level of glutathione was observed in the products prepared with turnip roots poweder, but this rise was moderate due to the influence of glutathione by heat during frying. This was also shown by Jenna et al. (2015) who concluded that cooked foods that are exposed to heat and various treatments for a short time contain more glutathione than foods that are exposed to large processing operations. It was also found that fresh fruits and vegetables have excellent levels of glutathione compared to cooked foods that contain much less.

Glutathione is a tripeptide (glycine, cysteine and glutamic acid) and is found in high concentrations in many bodily tissues and has many benefits as it promotes metabolic detoxification and maintains oxidative balance, reducing oxidative stress and regulating the immune system (Pizzorno, 2014). Glutathione is found in raw meat at a rate of $50-200 \mathrm{mg}$ / $\mathrm{kg}$ wet weight $(175-600 \mu \mathrm{mol} / \mathrm{kg}$ wet $\mathrm{wt})$ and fried chicken (without skin) contains $6.5 \mathrm{mg} / 100 \mathrm{~g}$ (Jones et al., 1992). Poultry is also a good source of sulfur, which has been found to be closely related to the production of glutathione (Grimble, 2006). It is also found in many fresh vegetables and fruits such as watermelon, asparagus, peaches, avocado, spinach, 
Table 6. Glutathione contentof turnip roots powder and its products

\begin{tabular}{|c|c|c|c|c|c|}
\hline Parameter & $\begin{array}{c}\text { Turnip root } \\
\text { powder }\end{array}$ & Chic & nuggets & & fel \\
\hline \multirow[b]{2}{*}{$\begin{array}{l}\text { Glutathione } \\
(\mathrm{mg} / \mathrm{kg})\end{array}$} & \multirow{2}{*}{$7.50 \pm 0.10$} & Control & Nug/Br** & Control & Fal/Br**** \\
\hline & & $13.80 \pm 0.73^{\mathrm{b}}$ & $19.11 \pm 0.10^{\mathrm{a}}$ & $8.85 \pm 0.02^{\mathrm{b}}$ & $13.17 \pm 0.17^{\mathrm{a}}$ \\
\hline
\end{tabular}

Key: $\mathrm{Nug} / \mathrm{Br}^{* *}$ : Chicken nuggets supplemented with turnip root powder $\%$

$\mathrm{Fal} / \mathrm{Br} * * *:$ Falafel supplemented with turnip root powder\%

tomatoes, red beets, potatoes, broccoli and others at a rate ranging from $40-150 \mathrm{mg} / \mathrm{kg}$ wet weight (140-450 $\mu \mathrm{mol} / \mathrm{kg}$ wet wt) (Demirkol et al., 2004).So if a person consumes enough food rich in glutathione, he will already have enough glutathione in his body.

Brassica is a nutritional source rich in glutathione. The recommended dosage from Brassica vegetables was $250 \mathrm{~g}$ glutathione /day (Minich and Brown 2019).Consumption of vegetables, in particular Brassica vegetables, was positively associated with glutathione $S$ transferase (GST) enzyme activity. Also, Kapusta-Duch et al. (2012) mentioned that fresh vegetables contain enzymes that have an antioxidant effect like superoxide dismutase, catalase, and glutathione peroxidase. Experiments with different turnip extracts and fractions have been reported by Gul et al. (2013), who found that crude extract from turnip roots improved the level of glutathione peroxidase (GPx), superoxide dismutase (SOD) and total antioxidant status (TAS) in blood samples of rats.

\section{Acrylamide content in chicken nuggets and Falafel supplemented with turnip roots powder versus their controls:-}

The changes in acrylamide content after supplementation of chicken nuggets and Falafel with turnip powder are summarized in Figure (4). The supplementation of chicken nuggets with turnip caused a decrease in acrylamide content from $3.76 \pm 0.31$ to $2.25 \pm 0.62 \mu \mathrm{g} / \mathrm{kg}$. Also, the adding of turnip roots powder in the preparation of Falafel caused a decrease in acrylamide content from $3.42 \pm 0.68$ to $2.56 \pm 0.13$ $\mu \mathrm{g} / \mathrm{kg}$.

The high concentrations of acrylamide found in the chicken nuggets imply that the rusk powder used to form the chicken crust could not be the sole source of acrylamide. Instead, the interaction between the carbohydrates from the rusk powder and the free amino acids from both the egg and the chicken meat most likely ultimately led to the formation of such high concentrations of acrylamide. The effect of egg protein on the formation of acrylamide in starch-rich foods has also been observed by Tareke et al. (2002), who reported significant differences in acrylamide content in fried potatoes mixed with milk, egg, or flour compared with potatoes without such additives. The effect of these combined sources of acrylamide becomes more pronounced when comparing the concentrations in the chicken samples with those reported for fried or roasted meat products free of carbohydrate-containing additives.

Acrylamide is formed in Falafel as a result of the frying process and also as a result of containing protein. This is consistent with Salazar et al. (2012) who showed that acrylamide formed during frying, baking or roasting starchy rich food and also in food containing a high protein concentration and sulfhydryl groups. Al-Dmoor et al. (2004), indicated that acrylamide in Jordanian fried Falafel cooked for $6-8 \mathrm{~min}$ at $160-180 \mathrm{c}^{\circ}$ is present in very high values ranging from 2700 to 4200 $\mu \mathrm{g} . \mathrm{kg}^{-1}$, moreover, the same study demonstrated that the excessive use of frying oil in food preparation causes significant increases $(\sim 33 \%)$ in acrylamide content. Also, Abo Leila et al. (2016) found the acrylamide level in commercial fried Falafel was176 $(\mu \mathrm{g} / \mathrm{kg})$. This large amount of acrylamide is due to the preparation of Falafel in an oil that has been used more than once, but in this study, chicken nuggets and Falafel were prepared in an oil that is used for the first time, so the amount of acrylamide formed was not large, but was higher than the amount determined by FAO/WHO, which represent $0.3-0.8 \mu \mathrm{g} / \mathrm{kg}$ body weight/day in developing countries. Additionally, FAO/WHO(2002) identified the maximum daily allowed (MDA) dose of acrylamide for woman $(60 \mathrm{~kg})$, man $(82 \mathrm{~kg})$ and child $(18 \mathrm{Kg})$ as 30,41 and $9 \mathrm{mg}$, respectively. Therefore, the acrylamide content in most commonly foods in Egypt such as Falafel and chicken nuggets may produce health problems for all people at long time because of their widespread consumption. Numerous research has shown that acrylamide and its biotrans formed metabolite, glycidamide, pose a great risk to many parts of the body such as the kidneys, lungs, intestines and liver, in addition to having reproductive and neurotoxic toxicity (Capuano and Fogliano 2011) 


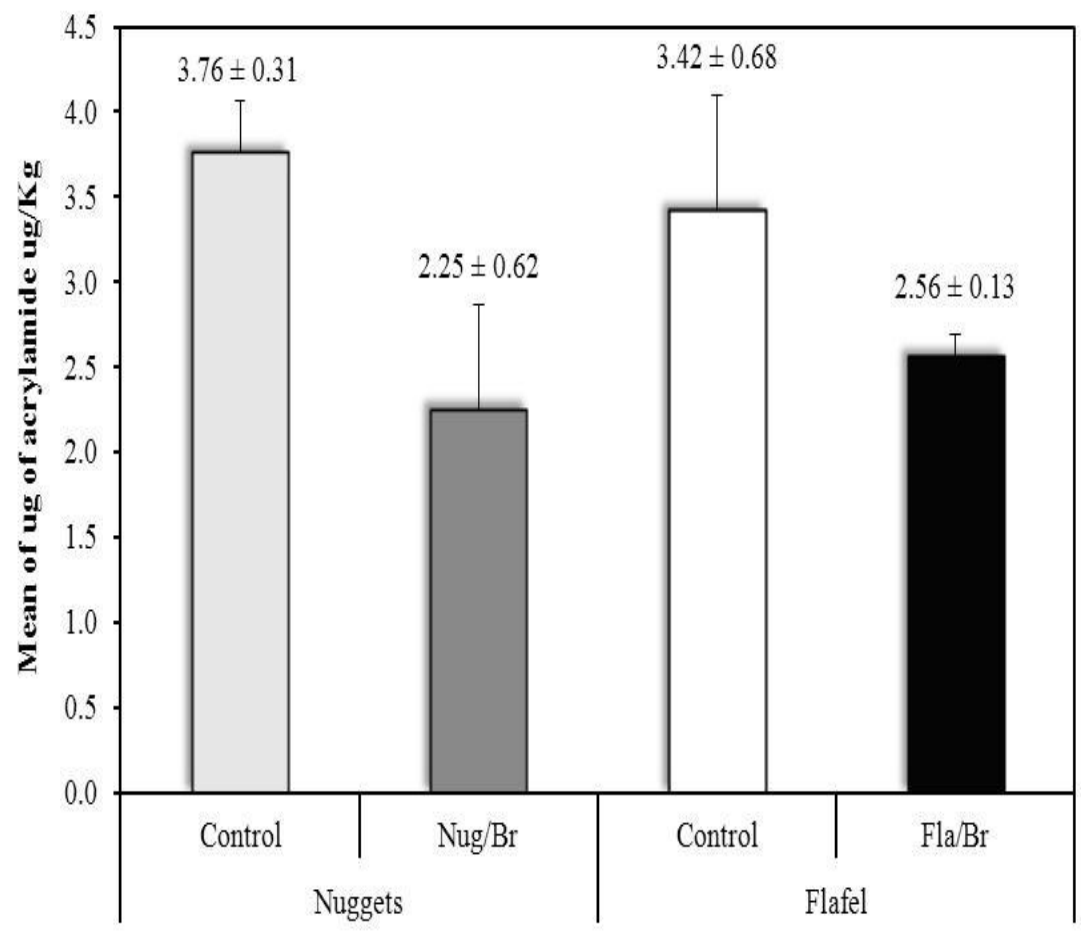

Figure 4. Acrylamide content in the chicken nuggets and Falafel.

Key: Nug/Br**: Chicken nuggets supplemented with turnip root powder \%

$\mathrm{Fal} / \mathrm{Br}^{* * *}:$ Falafel supplemented with turnip root powder $\%$

In the present study, frying was done using a mixture of soybean oil and sunflower oil, as soybean oil has a low degree of smoking followed by sunflower oil, and their use reduces the formation of acrylamide, so soybean oil and sunflower are considered safer when used in the frying process. The results indicated that the addition of turnip to chicken nuggets and Falafel led to a decrease in acrylamide content, this may be due to the richness of the turnip content of total phenols and flavonoids. The plant polyphenols proved to be beneficial to human because they are very strong antioxidants. Many studies indicated that when foods are heated, the formation of acrylamide is influenced by the polyphenols. On the other hand, this effect of the polyphenols on acrylamide formation depends on their concentrations, antioxidant potency and structure as well as the condition of the reaction. Acrylamide formation can be prevented by polyphenols via preventing the lipid oxidation and trapping of carbonyl compounds (Liu et al., 2015).

It is well known that the oxidative effect plays an essential role in the development of acrylamide nephrotoxicity (Morsy et al., 2014). But, some researches mentioned that particularly phenolic-rich pure compounds, hydroxylic antioxidants, and extracts, could lower the acrylamide formation (Kalita et al., 2013). Moreover, Bassama et al. (2010) revealed that flavonoids have the ability to lower the formation of acrylamide in both real food matrices and chemical model systems. In a similar previous study (Kocadagl $e t$ al., 2012) it was found that flavonoids act as antioxidants, they can lower the formation of acrylamide by inhibiting lipid oxidation, and limiting the accumulation of carbonyl.

Acrylamide causes Glutathione (GSH) depletion in the body, and this depletion leads to redox imbalance due to reactions with hydrogen peroxide (Kopanska et al., 2015). Therefore, foods rich in glutathione, such as turnip are foods that counteract the harmful effect of acrylamide by improving the level of glutathione in the body.

The concentration of acrylamide in foods depend on several factors including type of food, repeating and frying processes condition, type of frying oil, concentration of reducing sugars (specially glucose) and amino acids specially asparagine, temperature, time, cultivated processes of plants and finally the food preparation methods and processes depending on the nationalities. Therefore, the use of natural foodstuffs that have a role in reducing acrylamide formation has a 
great importance in reducing the risks caused by acrylamide.

\section{CONCLUSION}

The addition of turnip roots powder in Falafel and chicken nuggets increased their phenolics, flavonoids compounds, glutathione and antioxidant activity, in addition to that reduced the acrylamide content in these fried products, which indicates that the turnip roots is rich in many healthy compounds with high nutritional value.

\section{REFRENCES}

Al-Dmoor, H.M., M.A.Humeid and M.A. Alawi. 2004. Investigation of acrylamide levels in selected fried and bakedfoods in Jordan. J. Food Agric. Environ. 2:157-165.

Ali, H and N. Naz. 2017. Free radical scavenging activity or pulps and peels of some selected vegetables commonly used in pakististan. Pakistan J. Agric. Res. Vol. 30 No.1: 55-66.

Aljdely, A.A and H.M. Hemida. 2002. Evaluation of foods, Arab Nile Group, Cairo.

Association of Official Analytical Chemists, AOAC. 2007. Official Methods of Analysis of the A.O.A.C. International, $18^{\text {th }}$ edn, AOAC, Gaithersburg, Maryland, USA.

Abdullah, T. 2015. Reduction of oil uptake in deep fat fried Falafel. J. Nutr. Health Food Eng. 2: 114-117.

Abo Leila, I. M., M. M. Ahmed, R. M. Abd El-Azeem, A. M. Othman and A. E. A. Hemeida .2016. Reducing of Acrylamide Content in Fried Egyptian Foods Using someNaturalCompounds.J. Drug Res. Egypt, Vol . 37, No.1: 1-8.

Amr, A. and M. Abdulla. 2003. Chemical and physical changes in palm olein and soybean oil during Falafel frying. Proceedings of the International Palm oil conference. 2003, Kuala Lumpur, Malaysia.

Barros, J. C., P. E. S.Munekata, M. A.Pires, I.Rodrigues, O. S.Andaloussi, C. E. C.Rodriguesand M. A. Trindade.2018. Omega-3- and fibre-enriched chicken chicken nuggets by replacement of chicken skin with chia (Salvia hispanica L.) flour. Lebensmittel-Wissenschaft + Technologie, 90: 283-289. http://dx.doi.org/10.1016/j.lwt.2017.12.041.

Bassama, J., P.Brat, P.Bohuon, R.Boulanger and Z.Günata. 2010. Study of acrylamide mitigation in model system: Effect of pure phenolic compounds. Food Chemistry, 123:558-562.

Bastida, S. and F. J. Sánchez-Muniz. 2001. Thermal oxidation of olive oil, sunflower oil and a mix of both oils during forty discontinuous domestic fryings of different foods. Food Science and Technology International, 7: 15-21.

Beltagy, A.M. 2014. Investigation of new antimicrobial and antioxidant activities of Brassica rapa L. Int J Pharm Pharm Sci, 6: 84-88.
Berdja, S., L.Smail, B.Saka, S.Neggazi, E. Haffaf,Y.Benazzoug, G.Kacimi, L. Boudareneand S.Aouichat Bouguerra. 2016. Glucotoxicity Induced Oxidative Stress and Inflammation In Vivo and In Vitro in Psammomys obesus: Involvement of Aqueous Extract of Brassica rapa rapifera. Evidence-based complementary and alternative medicine, 3689208: 1-14.

Brand-Williams, W., M.Cuvelier and C.Berset. 1995. Use of a free radical method to evaluate antioxidant activity. LWTFood science and Technology, 28: 25-30.

Campbell, B., D.Han, C.M.Triggs, A.G. Fraserand L.R. Ferguson.2012. Brassicaceae: nutrient analysis and investigation of tolerability in people with Crohn's disease in a New Zealand study. Functional Foods in Health and Disease, 2, 460-486.

Capuano, E. and V. Fogliano. 2011. Acrylamide and 5hydroxymethylfurfural (HMF): a review on metabolism, toxicity, occurrence in food and mitigation strategies. LWT Food Sci Technol;44:793-810.

Cartea, M.E., Francisco, M., Soengas, P. and Velasco, P. 2010. Phenolic compounds in Brassica vegetables. Molecules, 16: 251-80.

Czarnowska, M and E.Gujska. 2012. Effect of freezing technology and storage conditions on folate content in selected vegetables. Plant foods for human nutrition (Dordrecht, Netherlands), 67: 401- 406.

Demirkol, O., C.Adams and N. Ercal.2004. Biologically important thiols in various vegetables and fruits. J. Agric Food Chem.. 52: 8151-8154.

Djeridane, A., M.Yousfi, B.Nadjemi, D.Boutassouna, P.Stocker and N.Vidal. 2006. Antioxidant activity of some algerian medicinal plants extracts containing phenolic compounds. Food Chemistry, 97: 654-660.

Elfalleh, W., N.Nasri, N.Marzougui, I.Thabti, A.M'Rabet, Y.Yahya, B.Lachiheb, F.Guasmi and A.Ferchichi. 2009. Physico-chemical properties and DPPH-ABTS scavenging activity of some local pomegranate (Punica granatum) ecotypes. International Journal of Food Sciences and Nutrition, 60 Suppl 2: 197-210.

FAO/WHO. 2002. Consultation on health implication of acrylamide in food, Geneva, juna,2527http:/www.Who.int/fsf/acrylamide/sum maryreportfinal.pdf.

Fernandes, F., P.Valentão, C.Sousa, J.A.Pereira, R.M. Seabra and P.B. Andrade. 2007. Chemical and antioxidative assessment of dietary turnip (Brassica rapa var. rapa L.). Food Chemistry, 105: 1003-1010.

Folch, J., M. Lees and S. Stanley. 1987. A simple method for the isolation and purification of total lipids from animal tissues. Journal of biological chemistry, 236: 497-509.

Gökmen, V., H.Z.Senyuva,J.Acarand K.Sarioğlu. 2005. Determination of acrylamide in potato chips and crisps by high-performance liquid chromatography. J Chromatogr A. Sep 23;1088(1-2):193-199. 
Goupy, P., M. Hugues, P. Boivin and M. J. Amiot. 1999. Antioxidant composition and activity of barley (Hordeum vulgare) and malt extracts and of isolated phenolic compounds. Journal of the Science of Food and Agriculture, 79: 1625-1634.

Grimble RF. 2006. The effects of sulfur amino acid intake on immune function in humans. J Nutr. 136 (6 Suppl):1660S$1665 \mathrm{~S}$.

Grumbles, S.L. 2008. Optimization of Ingredient and Process Parameters for Chicken Chicken nuggets, Oklahoma State University.Master ofscience .

Gul, S., S.Ahmed, H.Gul, K.F.Shad, M.Zia-Ul-Haq and D. Badiu. 2013. The antioxidant potential of Brassica rapa L. on glutathione peroxidase, superoxide dismutase enzymes and total antioxidant status. Romanian Review of Laboratory Medicine, 21: 161-169.

Harbaum, B., E.M.Hubbermann, C.Wolff, R.Herges, Z.Zhu and K.Schwarz. 2007.Identification of flavonoids and hydroxycinnamic acids in pakchoi varieties (Brassica campestris L. ssp. chinensis var. communis) by HPLCESI-MSn and NMR and their quantification by HPLCDAD. Journal of Agricultural and Food Chemistry, 55: 8251-60.

Harput, U., Y.genç, N.Khan and I.Saracoglu. 2010. Radical Scavenging Effects of Different Veronica Species. Records of Natural Products, 5: 100-107.

Higdon, J.V., B.Delage, D.E.Williams and R.H. Dashwood. 2007. Cruciferous vegetables and human cancer risk: epidemiologic evidence and mechanistic basis. Pharmacological Research, 55: 224-36.

Hussain, J., N.U.Rehman, Z.K.Shinwari, L.Ali, A.Al-Harrasi, A.L. Khan and F.Mabood. 2013. Qualitative characteristics of the commonly used vegetables in Usterzai of Kohat region. Pakistan Journal of Botany, 45: 2071-2074.

Ismail, M. ,H. K. Kim, Y. H.Choi and R.Verpoorte.2017. Falafel: A Meal with Full Nutrition. Food and Nutrition Sciences, 8:1022-1027.

Jahangir, M., H.K.Kim, Y.H. Choi and R.Verpoorte. 2009. Health-Affecting Compounds in Brassicaceae. Comprehensive Reviews in Food Science and Food Safety, 8: 31-43.

Jenna, M., T. Rong, Z.Yuhan and M. Yoshinori .2015. Effects of cooking on rutin and glutathione concentrations and antioxidant activity of green asparagus (Asparagus officinalis) spears. J. of Functional Foods.12:342-353.

Jin, D., H.Hakamata, K.Takahashi, A.Kotani and F.Kusu. 2004. Separation of flavonoids by semi-micro highperformance liquid chromatography with electrochemical detection. Bulletin of the Chemical Society of Japan, 77: 1147-1152.

Jones, D. P., R. J. Coates, E. W. Flagg, J. W. Eley, G. Block, R. S. Greenberg, E. W. Gunter and B. Jackson. 1992.Glutathione in foods listed in the national cancer institute's health habits and history food frequency questionnaire. Nutrition and Cancer. Vol. 17, No. 1: 5775.
Kalita, D., D.G. Holm and S.S. Jayanty. 2013. Role of polyphenols in acrylamide formation in the fried products of potato tubers with colored flesh. Food Research international, 54: 753-759.

Kapusta-Duch, J., A.Kopec, E.Piatkowska, B.Borczak and T.Leszczynska. 2012. The beneficial effects of Brassica vegetables on human health. RocznikiPanstwowegoZakladuHigieny, 63: 389-95.

Kaur, C and H. C. Kapoor. 2002. Antioxidant activity and total phenolic content of some Asian vegetables. Int. J. Food Sci. Technol. 3: 153-161.

Kirkpatrick, L. A. and B. C. Feeney. 2013. A simple guide to IBM SPSS statistics for version 20.0. Student ed, Wadsworth, Cengage Learning, Belmont, Calif.

Kopanska, M., N. Lukac, E. Kapusta and G. Formicki. Acrylamide influence on activity of acetylcholinesterase, thiol groups, and malondialdehyde content in the brain of swiss mice. J Biochem Mol Toxicol, 29:472-872.

Kotz, S., N.Balakrishnan, C.B. Read and B. Vidakovic. 2006. Encyclopedia of statistical sciences, $2^{\text {nd }} e d n$, WileyInterscience, Hoboken, N.J.

Liang, Y.S., H.K.Kim, A.W.Lefeber, C.Erkelens, Y.H. Choiand R.Verpoorte. 2006. Identification of phenylpropanoids in methyl jasmonate treated Brassica rapa leaves using two-dimensional nuclear magnetic resonance spectroscopy. Journal of Chromatography A, 1112: 148-55.

Lipsa, D., C. Cacho, P.Leva, J.Barrero-Moreno and P.Aguar. 2015. Development of a HPLC-UV method for the simultaneous determination of intracellular glutathione species in human cells. J Anal Bioanal Tech, 6: 259.

Liu, Y., P.Wang, F. Chen,Y.Yuan, Y.Zhu, H.Yan and X.Hu. 2015. Role of plant polyphenols in acrylamide formation and elimination. Food Chemistry, 186: 46-53.

Minich, D. M. and B. I. Brown. 2019. A Review of Dietary (Phyto)Nutrients for Glutathione Support. Nutrients. Sep; 11(9): 2073.

Morales-Lopez, J., M. Centeno-Alvarez, A. Nieto-Camacho, M. G. Lopez, E. Perez-Hernandez and E. FernándezMartínez . 2017. Evaluation of antioxidant and hepatoprotective effects of white cabbage essential oil. Pharm Biol 55: 233-4.

Morsy, M.A., S.A.Ibrahim, E.F.Amin, M.Y.Kamel, R.A. Rifaai and M.K. Hassan. 2014. Sildenafil ameliorates gentamicin-induced nephrotoxicity in rats: role of iNOS and eNOS. Journal of Toxicology: 1-7.

Mousavinejad, G., Z.Emam-Djomeh, K.Rezaei and M.H.H. Khodaparast. 2009. Identification and quantification of phenolic compounds and their effects on antioxidant activity in pomegranate juices of eight Iranian cultivars. Food Chemistry, 115: 1274-1278.

Ngonda, F. 2013.In vitro Anti-oxidant activity and free radical scavenging potential of roots of Malawian (Trichodesmazeylanicumm) (burn. F.). Asian Journal of Biomedical and Pharmaceutical Scienes, 3: 1-5.

Pizzorno, J. 2014. Glutathione! Integr. Med., 13: 8-12. 
Podsędek, A. 2007. Natural antioxidants and antioxidant capacity of Brassica vegetables: A review. LWT - Food Science and Technology, 40: 1-11.

Rokayya, S., C.J.Li, Y.Zhao, Y.Liand C.H.Sun.2014.Cabbage (Brassica oleracea L. var. capitata) phytochemicals with antioxidant and anti-inflammatory potential. Asian Pacific Journal of Cancer Prevention, 14: 6657-62.

Romani, A., P.Vignolini, L.Isolani, F.Ieri and D.Heimler. 2006. HPLC-DAD/MS characterization of flavonoids and hydroxycinnamic derivatives in turnip tops (Brassica rapa L. subsp. sylvestris L.). Journal of Agricultural and Food Chemistry, 54: 1342-1346.

Ryu, J.P., D. C. Kim, M. J. In, H. J. Chae, and S. D. Lee. 2012. Antioxidant potential of ethanol extract of Brassica rapa L. root. Journal of Medicinal Plants Research, 6: 1581-1584.

Saba, N. H. 2005. Cooking is science and art, Dar El-maaref, Egypt (In Arabic).

Saeed, M. K., S. Anjum, I.Ahmad, Alim-un-Nisa, S.Ali and A.Zia.2012. Nutritional facts and free radical scavenging activity of turnip (Brassica rapa) from Pakistan. World Applied Sciences Journal, 19: 370-375.

Salazar, R., G. Arámbula-Villa, F. J. Hidalgo and R. Zamora. 2012. Mitigating effect of piquin pepper (Capsicum annuumL. var. Aviculare) oleoresin on acrylamide formation in potato and tortilla chips. LWT-Food Sci. Technol.48: 261-267. [CrossRef]

Santhi, D. and A.Kalaikannan. 2014. The Effect of the Addition of Oat Flour in Low-Fat Chicken Chicken nuggets. J Nutr Food Sci: 4-1.

Schlesier, K., M.Harwat, V. Bohm and R.Bitsch. 2002. Assessment of antioxidant activity by using different in vitro methods. Free Radical Research, 36: 177-87.

Shafek, R., H.Michael, A.Sayed, A.Ibrahim and A.Al-sayed. 2018. Phytochemical Study, Antioxidant and Cytotoxic Activities of Brassica rapa L. leaves Extract and Its Silver Nanoparticles. Egyptian Journal of Chemistry, 61: 237247.

Shedeed, N.A. 1999. "Evaluation of microwave cooking of chicken meat." M.Sc. Thesis, Fac. Agric., Cairo University.

Sousa, C., M.Taveira, P.Valentao, F.Fernandes,J.A.Pereira, L.Estevinho, A.Bento, F.Ferreres, R.M. Seabraand P.B.Andrade, 2008. Inflorescences of Brassicacea species as source of bioactive compounds: A comparative study. Food Chem, 110: 953-61.
Stadler, R.H., I.Blank, N.Varga, F.Robert , J.Hau, P. A.Guy , M.C.Robert and S.Riediker. 2002. Acrylamide from Maillard reaction products. Nature. Oct 3;419(6906):44950.

Tareke, E., P.Rydberg, ,P.Karlsson, , S. Eriksson and M. Törnqvist. 2002. Analysis of acrylamide, a carcinogen formed in heated foodstuffs. Journal of Agricultural and Food Chemistry, 50:4998-5006.

Tamsen, M., H.Shekarchizadehand N.Soltanizadeh.2018. Evaluation of wheat flour substitution with amaranth flour on chicken nugget properties. Lebensmittel-Wissenschaft +Technologie, 91:580-587. http://dx.doi.org/10.1016/j.lwt .02 .001 .

Thiruvengadam, M., N.Praveen, K.M.John, Y. S.Yang, S. H. Kim and I. M. Chung. 2014.Establishment of Momordica charantia hairy root cultures for the production of phenolic compounds and determination of their biological activities. Plant Cell, Tissue and Organ Culture (PCTOC), 118: 545-557.

Totani, N., K. Satoh, S. Tsuji and A.Yamaguchi. 2006. Effects of deteriorated frying oil in Wistar rats. Journal of Oleo Science, 55: 291-7.

(USDA) United States Department of Agriculture.2008. Agricultural Research Service, National Nutrient Database for Standard Reference, Release 21. Nutrient Data.

(USDA) United States Department of Agriculture. 2019. Basic Report: 16138, Falafel, Home-Prepared.

Wachtel-Galor, S., K.W. Wongand I.F.F. Benzie. 2008. The effect of cooking on Brassica vegetables. Food Chemistry, 110: 706-710.

Wierzbicka, G. T., T. M. Hagen and D. P. Tones. 1989. Glutathione in food. Journal of Food Composition and Analysis. Volume 2, Issue 4 :327-337.

Zaied, S.A., M.Elgammal, N.S. Mahmoudand D.H. Alkhalifah.2016. Effect of baking conditions and antioxidants on acrylamide content of biscuit. International Journal of Scientific Engineering and Applied Science (IJSEAS), 2: 224-234.

Zambrano, F., P.Despinoy, R. Ormenese and Faria, E.V. 2004. The use of guar and xanthan gums in the production of 'light' low fat cakes. International Journal of Food Science \& Technology, 39: 959-966.

Zhang, H., I.Schonhof, A.Krumbein, B.Gutezeit, L. Li, H .Stu"tzel and M.Schreiner. 2008.Water supply and growing season influence glucosinolate concentration and composition in turnip root (Brassica rapa ssp. rapifera L.). J Plant Nutr Soil Sci 171:255-265. 


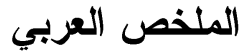

\section{تأثثير إضافة مسحوق جذور اللفت علي النشاط المضاد للاكسده ومحتوي الاكريلاميد في بعض الأغذيه المقلية}

مروة زكى محفوظ، استير فيكتور عبد النور، رجوى إبر اهيم عبد الرازق

الجلوتاثيون في الفلافل و الناجتس الدجاج بعد إضافة

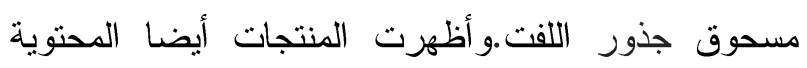

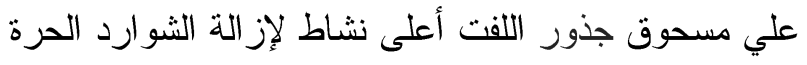

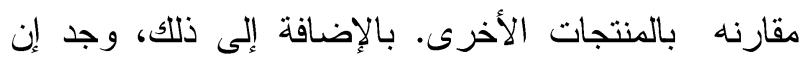
أعلى نسبة من مركبات الفلافونويدات، الفينولات الكلية، الجلوتاثيون والنشاط المضاد للأكسدة كانت في ناجنس الاجاج و الفلافل التي احتوت علي مسحوق جذور اللفت. على النقيض من ذلك فقد انخفض محتوى الأكريلاميد في علي

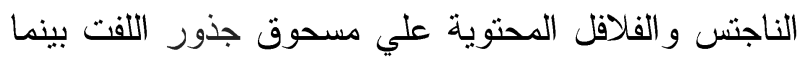
زاد في الكونترول. كانت هناك علاقة وثيقة بين محتوى

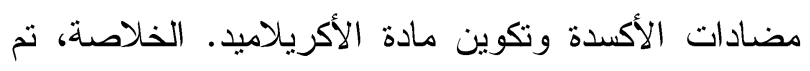
إثبات كفاءة جذور اللفت بوضوح من خلال النتايج التي تم

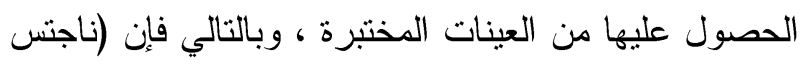

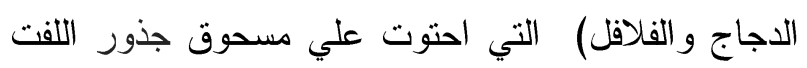

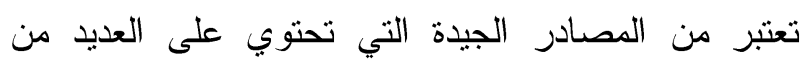

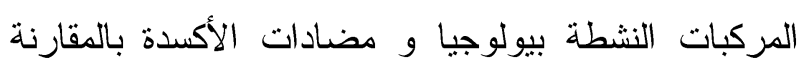
بالناجنس و الفلافل التي أعدت بالمكونات التقليدية

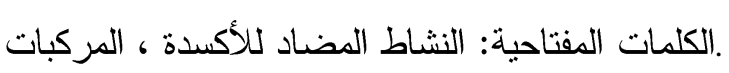

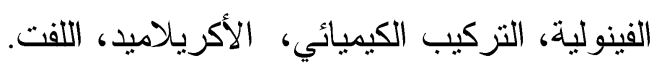

صمدت الدراسة الحالية بهدف إضافة مسحوق جذور اللفت إلى بعض الأطعمة المقلية و تثمل ناجنس الدجاج

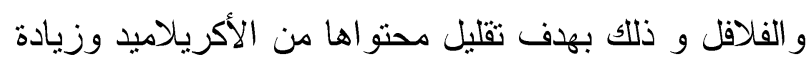

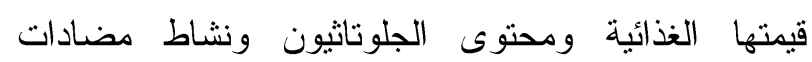
الأكسدة.. أعدت الفلافل بإضافة ثلاث نسب مختلفة من

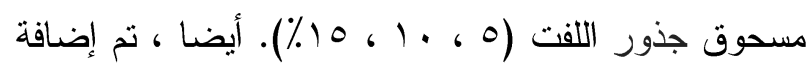

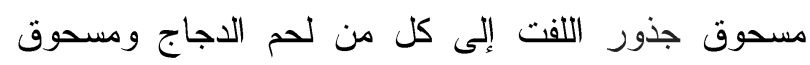

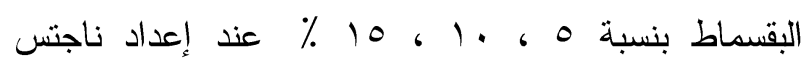
الدجاج. أظهرت النتائج أن أفضل نسبة مقبولة للناجتس

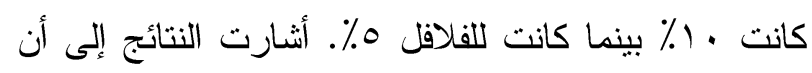

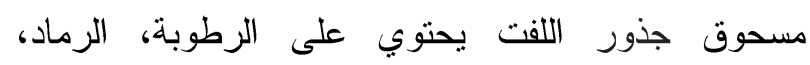

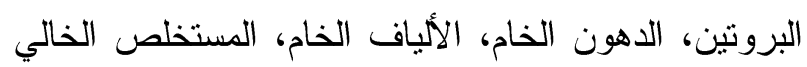

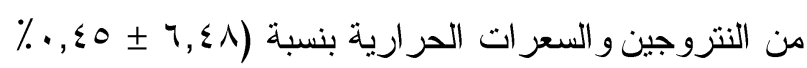
$\%, r r \pm \cdot, 07 ، \%, Y r \pm 0, \varepsilon V \cdot \% \cdot, r \pm \pm \cdot, r r$ 。 $\pm r V, \wedge \Lambda, \cdot \cdot \cdot 1 \pm \wedge 7, Y \leqslant, \%, V r \pm V, 0$. ،

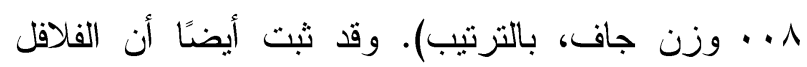

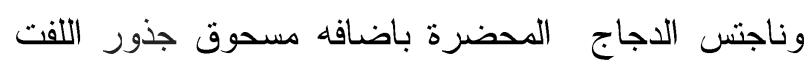
تحتوي على نسبة منخفضة من الدهون و السعرات الحرارية

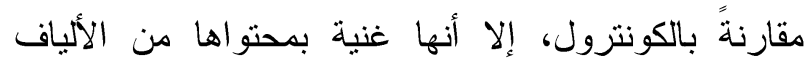

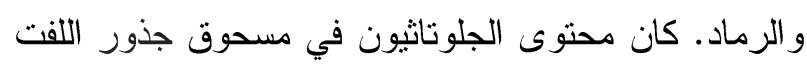

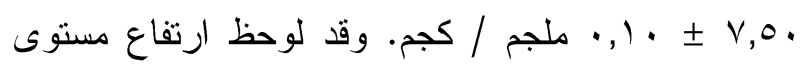

